\title{
An Endophytic Bacterial Strain Isolated from Eucommia ulmoides Inhibits Southern Corn Leaf Blight
}

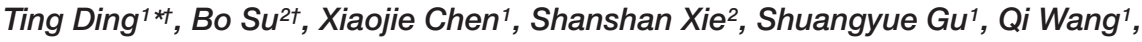 \\ Dayue Huang ${ }^{1}$ and Haiyang Jiang ${ }^{2 *}$ \\ ${ }^{1}$ School of Plant Protection, Anhui Agricultural University, Hefei, China, ${ }^{2}$ Key Laboratory of Crop Biology of Anhui Province, \\ Anhui Agricultural University, Hefei, China
}

OPEN ACCESS

Edited by:

Jens Staal,

Ghent University, Belgium

Reviewed by:

Birinchi Kumar Sarma,

Banaras Hindu University, India

Susan Breen,

Commonwealth Scientific and

Industrial Research Organisation

(CSIRO), Australia

${ }^{*}$ Correspondence:

Ting Ding

dingting98@126.com

Haiyang Jiang

hyjiang@ahau.edu.cn

tThese authors have contributed equally to this work.

Specialty section:

This article was submitted to Plant Microbe Interactions,

a section of the journal

Frontiers in Microbiology

Received: 22 February 2017 Accepted: 03 May 2017

Published: 18 May 2017

Citation:

Ding T, Su B, Chen X, Xie S, Gu S,

Wang $Q$, Huang $D$ and Jiang $H$

(2017) An Endophytic Bacterial Strain Isolated from Eucommia ulmoides Inhibits Southern Corn Leaf Blight.

Front. Microbiol. 8:903.

doi: 10.3389/fmicb.2017.00903
Bacillus subtilis DZSY21 isolated from the leaves of Eucommia ulmoides oliv. was labeled by antibiotic marker and found to effectively colonize the leaves of maize plant. Agar diffusion assays and biocontrol effect experiments showed that strain DZSY21 and its lipopeptides had antagonistic activity against Bipolaris maydis, as well as high biocontrol effects on southern corn leaf blight caused by B. maydis. Using MALDI-TOFMS analysis, we detected the presence of antimicrobial surfactin A, surfactin $B$, and fengycin in the strain DZSY21. Signaling pathways mediated by DZSY21 were analyzed by testing the expression of key plant genes involved in regulation of salicylic acid (SA) or JA/ET pathways, the defense-related genes $P R 1$ and $L O X$ were concurrently expressed in the leaves of DZSY21-treated plants; this corresponded to slight increase in the expression level of PDF1.2 and decreases in ERF gene transcription levels. The results indicated an induced systemic response that is dependent on the SA and jasmonic acid (JA) pathways. Thus, we hypothesized that the strain DZSY21 inhibits B. maydis by producing antifungal lipopeptides and activating an induced systemic response through SA- and JA-dependent signaling pathways. This work describes a mechanism behind reduced disease severity in plants inoculated with the endophytic bacteria DZSY21.

Keywords: endophytic bacteria, southern corn leaf blight, lipopeptides, colonization, induced systemic resistance

\section{INTRODUCTION}

Epidemics of southern corn leaf blight in maize are caused by Bipolaris maydis; these infections are regarded as one of the most destructive foliar diseases due to their extensive damage to crop yield and quality (Wang et al., 2015). Traditionally, fungicides and resistant cultivars have been used to control this disease in the field. Some fungicides, such as Chlorothalonil, Carbendazim, and Thiophanate-methyl wettable powders are effective in preventing disease (Akgül and Mirik, 2008); however, the use of chemical fungicides pollutes the environment and catalyzes the development of fungicide-resistant strains (Bajwa et al., 2003). Therefore, there is an interest in technologies that would reduce dependency on chemical pesticides. Biological pest control, including the use of microorganisms to control plant diseases, offers an attractive alternative that would alleviate many of the negative impacts of chemicals.

Endophytic bacteria are micro-organisms that colonize healthy plant tissue without causing any apparent symptoms or diseases to the host (Arnold et al., 2003). These strains could exert several beneficial effects on host plants, including conferring resistance against different biotic and abiotic stresses (Kharwar et al., 2008), inducing resistance to plant pathogens, and producing beneficial bioactive substances. There is interest in the use of endophytic bacteria for the biological 
control of plant diseases (Nejad and Johnson, 2000; Verhagen et al., 2004; Compant et al., 2005). So far, a variety of endophytes had been reported to confer protection against bacterial and fungal pathogens (Lodewyckx et al., 2002; Sessitsch et al., 2004). However, not enough is known about the mechanisms by which endophytic bacteria confer benefits. Understanding the mechanisms of biocontrol is critical to improving the efficacy of and implementing the use of biocontrol agents. The object of this study was to understand the inhibitory mechanisms by endophytic bacteria confer protection against disease.

Bacillus species are among the most common endophytic bacteria (Bacon and Hinton, 2002; Choudhary and Johri, 2009), and there are many reports describing the ability of Bacillus spp. to suppress several important plant pathogens (Melo et al., 2009). In recent years, Bacillus spp. have been used as a biocontrol agent to protect crops against plant diseases, and provide an alternative to chemical fungicides (Augustine et al., 2010; Yang et al., 2012; Zhou et al., 2014). The main biocontrol mechanisms of Bacillus spp. are considered to be the production of antibiotics (direct) (Ongena et al., 2005; Ongena and Jacques, 2008), such as lipopeptides which aroused great attention for suppressing the growth of fungal pathogens and stimulating the innate immunity of plant system against various pathogens (Ongena et al., 2007; Romero et al., 2007; Raaijmakers et al., 2010), the competition for ecological niches (direct) (Compant et al., 2005), or the induction of systemic resistance (ISR) in host plants (indirect) (Van Loon and Bakker, 2006; Saravanakumar et al., 2007). However, the effectiveness of endophytes as biological control agents (BCAs) is dependent on efficient colonization of the plant environment. The extent of endophytic colonization in host plant organs and tissues reflects the ability of bacteria to selectively adapt and compete in those specific ecological niches.

Eucommia ulmoides oliv. was a medicinal plant in southern China, which was known for hosting several metabolites having medicinal property (Matsuda et al., 2006; Zhang et al., 2014), and many studies on it had been carried out in terms of some products of secondary metabolism (Matsuda et al., 2006; Zhang et al., 2014). However, reports on the antagonistic endophytic bacteria isolated from the E. ulmoides oliv. and their potential to promote plant disease resistance were relatively few. In this study, the Bacillus subtilis DZSY21 isolated from the leaves of E. ulmoides oliv. exerts a strong antifungal effect on B. maydis. On that basis, we investigated the inhibition mechanisms of the biocontrol strain DZSY21, including direct antagonism and induced systematic resistance, as well as the ability of DZSY21 to colonize maize leaves. This work provides a theoretical basis for the use of DZSY21 as a replacement for pesticides and supplements.

\section{MATERIALS AND METHODS}

\section{Endophytic Bacterial Strain and Phytopathogen}

The leaves of E. ulmoides oliv., which were collected at Anhui Agricultural University $\left(31^{\circ} 86^{\prime} \mathrm{N}\right.$ and $\left.117^{\circ} 25^{\prime} \mathrm{E}\right)$ in the Anhui Province of China, were firstly washed in running water, and dipped in $70 \%$ ethanol for $1 \mathrm{~min}$ and then treated with $1 \%$ sodium hypochlorite for $10 \mathrm{~min}$. The samples were then washed several times with sterilized distilled water, the final wash was spread plated onto nutrient agar plate (g/L; peptone 5 , beef extract 2 , yeast extract 3, sodium chloride 5 and agar 18, $\mathrm{pH}$ 7.0) and cultivated at $28^{\circ} \mathrm{C}$ for 3 days as a sterility check. Samples were discarded if the growth was detected in the sterility check samples after 3 days (Tiwari et al., 2010; Sun et al., 2013).

For the isolation of endophytic bacterium DZSY21, $1 \mathrm{~g}$ of leaf tissues were fully grinded to homogenate in $9 \mathrm{ml}$ sterilized distilled water in a mortar, $100 \mu \mathrm{L}$ of the extract was taken and serial diluted up to $10^{-3}$ dilution. Then, $100 \mu \mathrm{L}$ was plated onto nutrient agar plate with three replications. The plates were incubated at $28-30^{\circ} \mathrm{C}$ for $48-72 \mathrm{~h}$. Each bacterium, as evident from their colony morphology was transferred to fresh nutrient agar medium plates to establish pure culture of endophytic bacterium. Lastly, endophytic bacterium DZSY21 was obtained and identified as Bacillus subtilis, the sequence data has been submitted to GenBank (accession No. KP777560). The strain was grown at $30^{\circ} \mathrm{C}$ for $24 \mathrm{~h}$ in beef-protein medium (beef extract $3 \mathrm{~g} / \mathrm{L}$, peptone $10 \mathrm{~g} / \mathrm{L}, \mathrm{NaCl} 5 \mathrm{~g} / \mathrm{L}, \mathrm{pH}$ 7.0-7.2). The cell density was adjusted to approximately $10^{8} \mathrm{CFU} / \mathrm{mL}$ in sterile distilled water for use.

The target phytopathogenic fungal strain, B. maydis, was obtained from the School of Plant Protection at Anhui Agricultural University. The strain was maintained on potato dextrose agar medium (potato $200 \mathrm{~g} / \mathrm{L}$, dextrose $20 \mathrm{~g} / \mathrm{L}$, agar $15 \mathrm{~g} / \mathrm{L}$ ). Conidia of $B$. maydis was induced on niblet culture (niblet $80 \mathrm{~g}, \mathrm{H}_{2} \mathrm{O} 10 \mathrm{~mL}$ ) incubated at $28^{\circ} \mathrm{C}$ for 10 days under a 12-h of light/dark cycle. The cultures were washed in sterile water and the mycelia were filtered through four layers of gauze to obtain conidia suspension. The concentration of the conidia suspension was adjusted to approximately $10^{5} \mathrm{CFU} / \mathrm{mL}$ using a hemocytometer.

\section{Extraction of Lipopeptides}

DZSY21 was grown in Landy medium (Glucose $20 \mathrm{~g} / \mathrm{L}$, Lglutamic acid $5 \mathrm{~g} / \mathrm{L}, \mathrm{MgSO}_{4} 0.5 \mathrm{~g} / \mathrm{L}, \mathrm{KCl} 0.5 \mathrm{~g} / \mathrm{L}, \mathrm{KH}_{2} \mathrm{PO}_{4}$ $1 \mathrm{~g} / \mathrm{L}, \mathrm{FeSO}_{4} \cdot 6 \mathrm{H}_{2} \mathrm{O} 0.15 \mathrm{mg} / \mathrm{L}, \mathrm{MnSO}_{4} 5.0 \mathrm{mg} / \mathrm{L}, \mathrm{CuSO}_{4} \cdot 5 \mathrm{H}_{2} \mathrm{O}$ $0.16 \mathrm{mg} / \mathrm{L}, \mathrm{pH} 7.0)$ at $30^{\circ} \mathrm{C}$ and $180 \mathrm{rpm}$ in a shaker for $38 \mathrm{~h}$. After centrifugation (5000 rpm, $15 \mathrm{~min}$ ), and cell-free supernatants (adjust to $\mathrm{pH} 2.0$ by with $6 \mathrm{M} \mathrm{HCl}$ ) were incubated overnight at $4{ }^{\circ} \mathrm{C}$. The acid precipitate was collected by centrifugation (8000 rpm for $10 \mathrm{~min}$ ) and extracted twice with methanol. The methanol extracts of acid precipitate were lipopeptides and the $\mathrm{pH}$ was adjusted to 7.0 with $\mathrm{NaOH}(2 \mathrm{M})$. The lipopeptides were concentrated using a vacuum freeze drier, and the dried material was dissolved in a suitable volume of methanol for further analysis.

\section{Antifungal Assays of the Strain DZSY21 and its Lipopeptides}

The inhibitory effect of endophytic bacterium DZSY21 on the growth of $B$. maydis was evaluated by the plate dual-culture method (Kunova et al., 2016). Firstly, a 5-mm mycelium disk cut from a 5-day-old culture of B. maydis was placed on the 
center of Petri dish, and cultivated for 3 days in advance, then strain DZSY21 from 2-day-old culture was streaked across approximately $2.5 \mathrm{~cm}$ away from the disk in the center of the plates. Water was used as negative control. The plates were continued to incubate at $28^{\circ} \mathrm{C}$ for 4 days. The inhibitory activity of treatment was carried out using the following formula, where $\mathrm{DC}=$ radius of control, and $\mathrm{DT}=$ radius of fungal colony with treatment. The experiments were repeated in triplicate and the data presented here were the averages of three experiments.

$$
\text { Growth inhibition }(\%)=\frac{D C-D T}{D C} \times 100 \%
$$

The antifungal activity of lipopeptides was evaluated by disk diffusion assay (Bauer et al., 1966). Firstly, the disk of B. maydis was placed on the center of Petri dish and incubated for 3 days in advance, then filter paper disks $(5 \mathrm{~mm})$ were switched with $300 \mu \mathrm{g}$ of lipopeptides and placed in approximately $2.5 \mathrm{~cm}$ away from the disk, a methanol switched disk was used as the control. The plates were continued to incubate at $28^{\circ} \mathrm{C}$ for 4 days. Antifungal activity was determined by observing the inhibition of fungal growth around the disk. Then the fungal mycelia treated with the DZSY21 and its lipopeptides was examined under a microscope.

\section{Colonization Studies on Maize Leaves}

To study the ability of DZSY21 to colonize maize leaves, the Bacillus subtilis DZSY21 was labeled by antibiotic marker (Chen et al., 1995; Nautiyal et al., 2002; Bennett et al., 2003; Wang et al., 2010a). Firstly, the sensitive concentrations of the strain DZSY21 to antibiotics were analyzed, and sensitive concentrations of the strain DZSY21 to kanamycin and chloramphenicol were 7.5 and $1 \mu \mathrm{g} / \mathrm{mL}$, respectively. On that basis, the DZSY21 ${ }^{\text {Kan }}$ was obtained by transferring colonies to LB medium agar plates containing increasing concentrations of kanamycin (Serva; 5, 10, $15,20,25,50,100,150$, and $200 \mu \mathrm{g} / \mathrm{mL}$ ), then the DZSY2 $1^{\text {Kan }}$ was transferred to LB medium agar plates containing increasing concentrations of chloramphenicol $(0.5,1,5,10$, and $15 \mu \mathrm{g} / \mathrm{mL})$ and fixed concentration of kanamycin $(200 \mu \mathrm{g} / \mathrm{mL})$, lastly, the double-resistance strain DZSY21 ${ }^{\text {Kan,chl }}$ was obtained. The stability and antagonistic effect of the DZSY $21^{\text {Kan,chl }}$ were tested by 20 sub-cultures on LB agar with kanamycin $(200 \mu \mathrm{g} / \mathrm{mL})$ and chloramphenicol $(15 \mu \mathrm{g} / \mathrm{mL})$, incubating for $48 \mathrm{~h}$ at $30^{\circ} \mathrm{C}$, the stability of the DZSY2 $1^{\mathrm{Kan}, \mathrm{chl}}$ was determined by comparing the number of CFUs after the last subculture, the antagonistic effect was evaluated through the plate confrontation method. And the DZSY $21^{\text {Kan,chl }}$ was characterized by amplification and sequencing of a partial sequence of the 16S rDNA gene. The DZSY $21^{\mathrm{Kan}, \mathrm{chl}}$ were stored at $4^{\circ} \mathrm{C}$ on $\mathrm{LB}$ with kanamycin $(200 \mu \mathrm{g} / \mathrm{mL})$ and chloramphenicol $(15 \mu \mathrm{g} / \mathrm{mL})$.

To determine whether the strain could colonize plant leaves, maize leaves inoculated with the suspensions $\left(1 \times 10^{8} \mathrm{CFU} / \mathrm{mL}\right)$ of the double-resistance strain DZSY21 ${ }^{\text {Kan,chl }}$ (50 mL per plant) and incubated for $24 \mathrm{~h}$, maize leaves treated with sterile water were used as a control (50 mL per plant). The samples were collected at $24 \mathrm{~h}$ post-inoculation, they were treated and observed by transmission electron microscopy at biotechnology center of Anhui Agricultural University.
To analyze the population density of the strain in maize leaves, at the pumping stage of maize plant, suspensions of the double-resistance strain DZSY21 ${ }^{\text {Kan,chl }}$ were adjusted to $10^{8}$ $\mathrm{CFU} / \mathrm{mL}$ in sterile distilled water, and $50 \mathrm{~mL} /$ plant was applied to the maize leaves in each plant. Maize leaves treated with sterile water were used as a control $(50 \mathrm{~mL}$ per plant). Leaves were harvested at $1,3,5,7,10,15,20,25$, and 30 days after inoculation, and the population of the DZSY $21^{\text {Kan, chl }}$ inside the mesophyll tissue was estimated. The maize leaves were weighed, cut into small pieces, surface sterilized with $0.1 \%$ corrosive sublimate for $1 \mathrm{~min}$, treated with $1 \%$ sodium hypochlorite for $10 \mathrm{~min}$, and washed several times with sterilized distilled water. The sterilized plant material was trimmed, ground, and diluted with phosphate buffer saline (PBS) (sodium chloride $8 \mathrm{~g} / \mathrm{L}$, potassium chloride $0.2 \mathrm{~g} / \mathrm{L}$, disodium hydrogen phosphate $1.44 \mathrm{~g} / \mathrm{L}$, and potassium dihydrogen phosphate $0.24 \mathrm{~g} / \mathrm{L} ; \mathrm{pH} 7.4$ ) up to a dilution factor of $10^{-3}$. $100 \mu \mathrm{L}$ of each dilution was plated on LB medium containing kanamycin $(200 \mu \mathrm{g} / \mathrm{mL})$ and chloramphenicol $(15 \mu \mathrm{g} / \mathrm{mL})$. The plates were counted after $48 \mathrm{~h}$ incubation at $30^{\circ} \mathrm{C}$. This experiment was conducted in duplicate.

\section{Biocontrol Assays}

Plot experiments were carried out in the teaching practice base of Anhui Agricultural University in July 2015. Maize seedlings (Chang 7-2, F1) were grown in the soil with planting depth of $10 \mathrm{~cm}$. The soil was tilled twice before pre-sterilized $(3 \%$ sodium hypochlorite solution) maize seeds were planted. At the pumping stage, the maize plants were divided into four plots, and 40 plants were present in one plot. The efficacy of DZSY21 in suppressing southern corn leaf blight was evaluated by applying lipopeptides $(1 \mathrm{mg} / \mathrm{mL})$ and DZSY21 suspensions $\left(1 \times 10^{8} \mathrm{CFU} / \mathrm{mL}\right)$ by spraying the leaves of the maize plants (50 mL per plant). Sterile water and $50 \%$ carbendazim wettable powder 600 times liquid were used as the negative and positive controls, respectively. The conidial suspension of $B$. maydis $\left(1 \times 10^{5} \mathrm{CFU} / \mathrm{mL}\right)$ was applied to the leaves via the same mechanism $24 \mathrm{~h}$ after application of the treatment; the plants were then moistened with a humidifier for $12 \mathrm{~h}$. Each treatment was replicated 40 times and the experiment was repeated three times. The disease severity was recorded $4,6,8,10$, and 15 days after challenge with the pathogen according to a rating scale of 1-9 scales with 1 being the most resistant and 9 being dead (Balint-Kurti et al., 2007), and the Disease index and disease reduction were calculated according to the formulas below.

$$
\begin{aligned}
& \text { Disease index }=\frac{\Sigma\left(\mathrm{d}_{\mathrm{i}} \times \mathrm{l}_{\mathrm{i}}\right)}{\mathrm{L} \times \mathrm{N}} \times 100 \\
& \text { Disease reduction }=\left(\mathrm{I}_{0}-\mathrm{I}_{\mathrm{i}}\right) \times 100 \%
\end{aligned}
$$

where, $d_{I}=$ represents for the grade of disease severity, $l_{I}=$ the number of leaves at different grades of disease, $\mathrm{L}=$ the number of all investigated leaves, $\mathrm{N}=$ the highest grade of disease severity, $\mathrm{I}_{0}=$ the disease index of control, and $\mathrm{I}_{\mathrm{I}}=$ the disease index of different treatment groups. As a control, sterile water was spread on leaves. 
TABLE 1 | Primer sequences used for quantitative polymerase chain reactions.

\begin{tabular}{|c|c|c|c|}
\hline Gene & GenBank accession number & Primer name & Sequence \\
\hline PR-1 & U82200.1 & $\begin{array}{l}\text { PR-1-F } \\
\text { PR-1-R }\end{array}$ & $\begin{array}{l}\text { 5'-AACAATGGCACCGAGGCT-3' } \\
\text { 5'-GTAGTCCTGCGGCGAGTT-3' }\end{array}$ \\
\hline PDF1.2 & JF797205.1 & $\begin{array}{l}\text { PDF 1.2-F } \\
\text { PDF 1.2-R }\end{array}$ & $\begin{array}{l}\text { 5'-CCTCGTCCTCATGCTCCTCC-3' } \\
\text { 5'-ATGAGCCCGATGCTGGTG-3' }\end{array}$ \\
\hline LOX & NM_001111533.2 & $\begin{array}{l}\text { LOX-F } \\
\text { LOX-R }\end{array}$ & $\begin{array}{l}\text { 5'-AGGAGTTGGACGGGAGATT-3' } \\
\text { 5'-CCGTACTTGCTCGGGTCA-3' }\end{array}$ \\
\hline ERF & NM_001155962.1 & $\begin{array}{l}\text { ERF-F } \\
\text { ERF-R }\end{array}$ & $\begin{array}{l}\text { 5'-TAAGAGGTCTGCGGCTAACA-3' } \\
\text { 5'-TCATCGTCCCAGTCCCAC-3' }\end{array}$ \\
\hline Actin & DQ492681.1 & $\begin{array}{l}\text { Actin-F } \\
\text { Actin-R }\end{array}$ & $\begin{array}{l}\text { 5'-CGACTGCTGAGCGAGAA-3' } \\
\text { 5'-TGAAGGATGGCTGGAATA-3' }\end{array}$ \\
\hline
\end{tabular}

\section{Molecular Mass of DZSY21 Lipopeptides Determined by MALDI-TOF}

Lipopeptides were analyzed for surfactin, iturin, and fengycin using MALDI-TOF-MS. A sample $(1 \mathrm{mg} / \mathrm{mL})$ was diluted $10 \mathrm{x}$ with $100 \%$ methanol, and data was acquired in positive reflector mode from 800 to $4000 \mathrm{~m} / \mathrm{z}$. The analysis was performed at biotechnology center of Anhui Agricultural University.

\section{Study of Plant Defense Response}

The lower leaves (i.e., the first leaf to the fourth leaf) of axenic maize plants from nine different leaf periods were covered with DZSY21 (5 mL per leaf of $10^{8} \mathrm{CFU} / \mathrm{mL}$ ) and cultivated in the greenhouse $\left(30-35^{\circ} \mathrm{C}\right)$ under a 12 -h-light and 12 -h-dark interval. Control plants were covered with $5 \mathrm{~mL}$ (per leaf) of sterile water instead of the bacterial cell suspension. Then the bacterized and non- bacterized leaves from the upper part of the plants (i.e., the sixth leaf to the ninth leaf) were harvested at $12,24,36,48$, and $60 \mathrm{~h}$ for RNA extraction. Forty-five plants were present in each treatment, nine maize plants were harvested and divided into three replicates at different period, and each sample was mixtures of the upper leaves of the three maize plants.

Total RNA was extracted using the Trizol reagent (Invitrogen) according to the manufacturer's instructions. The DNase-treated RNA was reverse-transcribed using M-MLV reverse transcriptase (Invitrogen). The primer pairs used for the qRT-PCR analysis were designed according to parameters established for the Primer3Plus program (Untergasser et al., 2007; Klosterman et al., 2011) (Table 1). Expression of pathogenesis-related protein 1 $(P R 1)$, defensin (PDF1.2), lipoxygenase (LOX), and ethylene response factor $(E R F)$ were monitored by qRT-PCR in plants in response to DZSY21 treatment. The candidate reference genes actin was identified as the most stable gene and was used as an endogenous control in qRT-PCR analysis. qRT-PCR was performed on an ABI 7300 Real-Time System (Applied Biosystems). Each reaction contained $12.5 \mu \mathrm{L}$ of $2 \times$ SYBR Green Master Mix reagent (Applied Biosystems), $400 \mathrm{nM}$ of genespecific primers, and $1.5 \mu \mathrm{L}$ of diluted cDNA sample (final volume $20 \mu \mathrm{L}$ ). The thermocycle conditions were: $95^{\circ} \mathrm{C}$ for $10 \mathrm{~min}$, followed by 40 cycles of $95^{\circ} \mathrm{C}$ for $15 \mathrm{~s}$ and $60{ }^{\circ} \mathrm{C}$ for $60 \mathrm{~s}$. After the PCR was complete, a melting curve was generated to analyze the specificity for each gene by increasing the temperature from 60 to $95^{\circ} \mathrm{C}$. Three replicates were performed for each gene. Results are based on the average of triplicates, and the standard deviation of the mean is shown.

\section{Statistical Analysis}

The data of all experiments was analyzed by analysis of variance (ANOVA). When ANOVA showed treatment effects $(P<0.05)$, the least significant difference test (LSD) and Duncan's multiple range test (for maize) were applied to make comparisons among the means. The statistical package DPS ver. 9.50 was used for all analyses.

\section{RESULTS}

\section{Antifungal Activity of the Strain DZSY21 and Its Lipopeptides}

Lipopeptides are cyclic, low molecular weight antimicrobial compounds, which are mainly composed of a 7-10 amino acid hydrophilic head linked with a hydrophobic fatty acid tail (Cai et al., 2013). Bacillus species have strong antimicrobial properties and are known to produce a structurally diverse group of antimicrobial lipopeptides, including surfactin, iturin, and fengycin families (Wang et al., 2010b; Cai et al., 2013).

Screening of the endophytic strain DZSY21 for antifungal activity by the dual culture assay method showed antifungal activity by inhibition of fungal colony growth. After being cultured for 7 days, the diameter of the colony of the B. maydis treated with the strain DZSY21 was roughly $3 \mathrm{~cm}$ (Figure 1B), while the colony of $B$. maydis treated with water was basically full of Petri dish (Figure 1A). The strain DZSY21 exhibited antifungal activity against $B$. maydis with inhibition $61.70 \%$.

The isolated endophytic strain DZSY21 was grown in Landy medium for $38 \mathrm{~h}$ in order to induce secretion of antifungal lipopeptides. Cell-free supernatant was collected by centrifugation $(5000 \mathrm{rpm}, 15 \mathrm{~min})$ at $4^{\circ} \mathrm{C}$, the acid precipitate was obtained from cell-free supernatant by adding concentrated $\mathrm{HCl}$ to reduce $\mathrm{pH}$ at 2 and incubated overnight at $4^{\circ} \mathrm{C}$, the methanol extracts of acid precipitate were lipopeptides. The lipopeptides were assayed against the fungal pathogen $B$. maydis by disk diffusion assay. After being cultured for 7 days, the lipopeptides from DZSY21 exhibited antifungal activity against B. maydis, there was an obvious inhibition belt between the fungal colony and the disk with lipopeptides (Figure 1C-b), while the 

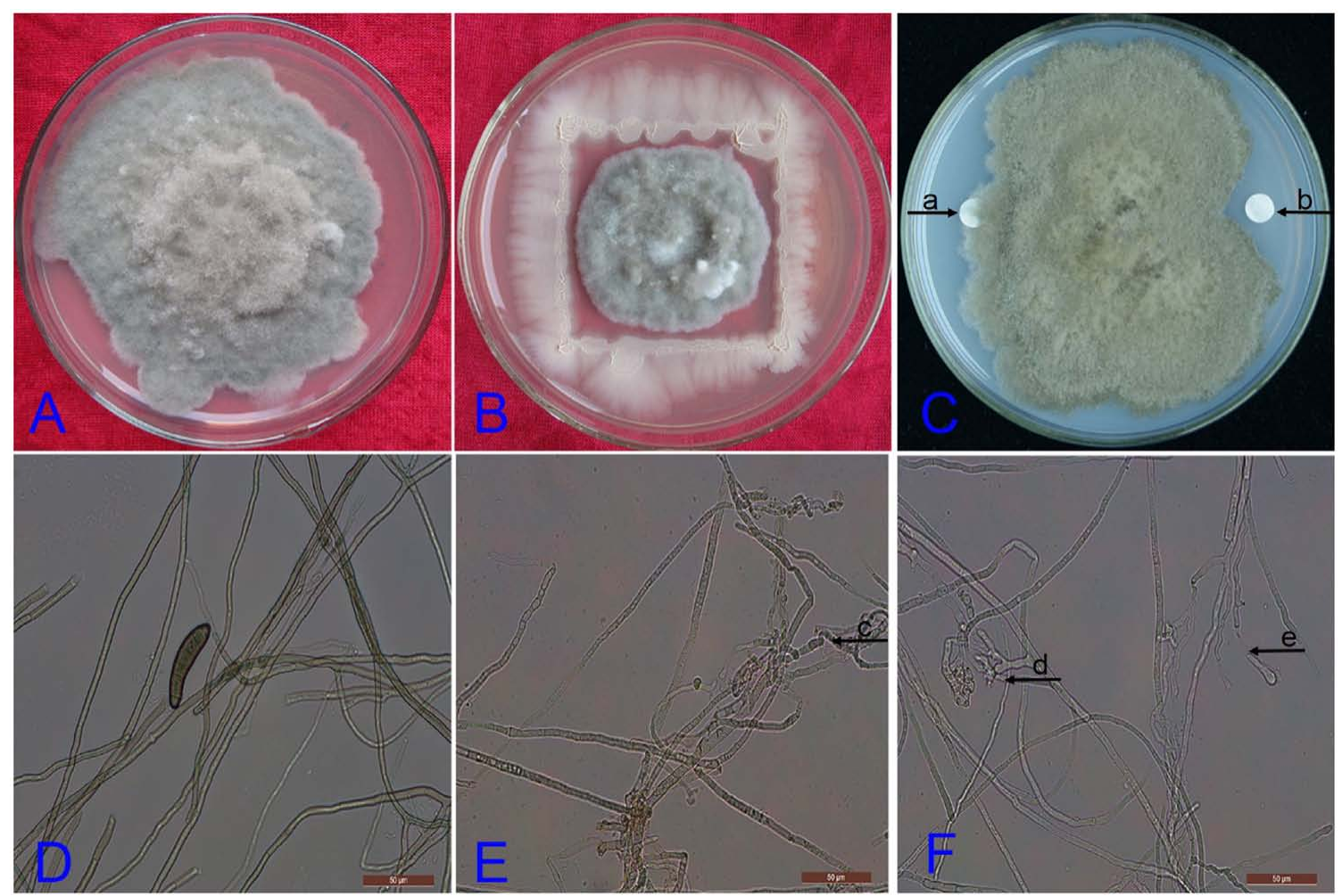

FIGURE 1 | Antifungal activity of Bacillus subtilis DZSY21 and its lipopeptides: (A) the colony of Bipolaris maydis treated with water incubated for 7 days; (B) the colony of B. maydis treated with the strain DZSY21 incubated for 7 days; (C) filter paper disks (5 mm) were switched with $300 \mu \mathrm{g}$ lipopeptides (a, filter paper disk switched with methanol; b, filter paper disk switched with lipopeptides); (D) microscopic images showing mycelium morphology of $B$. maydis treated with water; (E) microscopic images showing deformation in DZSY21 treated culture (c is the expansion and rupture of hyphae), and (F) microscopic images showing deformation in lipopeptides treated culture (d and $\mathbf{e}$ are the expansion and rupture of hyphae, respectively).

disk switched methanol was covered with hyphae of $B$. maydis (Figure 1C-a), the disk switched methanol had not antifungal activity against $B$. maydis. Microscopic examination of affected mycelia showed the DZSY21 could cause the mycelium inflation (Figure 1E-c), and some mycelia treated with lipopeptides were swelled, contorted (Figure 1F-d) and broken (Figure 1F-e). Meanwhile, the mycelium in the control plates (i.e., only treated with methanol) were smooth, vimineous, and evenly grown (Figure 1D).

\section{Ability of DZSY21 to Colonize Maize Leaves}

To investigate colonization ability of the endophytic strain DZSY21 in maize leaves, DZSY21 was tagged with kanamycin and chloramphenicol. The double-resistance strain DZSY2 $1^{\text {Kan,chl }}$ was selected on LB agar with kanamycin $(200 \mu \mathrm{g} / \mathrm{mL})$ and chloramphenicol $(15 \mu \mathrm{g} / \mathrm{mL})$. After approximately 20 generations of growth in the antibiotic medium with kanamycin $(200 \mu \mathrm{g} / \mathrm{mL})$ and chloramphenicol $(15 \mu \mathrm{g} / \mathrm{mL})$, the stability of the DZSY $21^{\text {Kan,chl }}$ were evaluated by comparing the number of CFUs after the last subculture, and analyzing the characteristics of colony of DZSY21 ${ }^{\mathrm{Kan}, \mathrm{chl}}$ and DZSY21. The results indicated the colonies of the DZSY21 ${ }^{\text {Kan,chl }}$
(Figure 2B) and the strain DZSY21 (Figure 2A) were all smooth, moist and milky white, and the number of CFUs of the DZSY $21^{\text {Kan, chl }}$ in different culture generation had no obvious difference. Additionally, the diameter of colony of B. maydis treated with the strain DZSY21 ${ }^{\mathrm{Kan}, \mathrm{chl}}$ (Figure 2D) was similar to that of the DZSY21 (Figure 1B), while the colony of B. maydis treated with water was basically full of Petri dish(Figure 2C). The antifungal activity of DZSY21 ${ }^{\mathrm{Kan}, \mathrm{chl}}$ was stable with $67.00 \%$ inhibition, compared to $61.85 \%$ for the wild-type strain DZSY21. And the DZSY2 $1^{\text {Kan,chl }}$ was also identified as Bacillus subtilis. Therefore, the double-resistance strain DZSY21 ${ }^{\text {Kan, chl }}$ was regarded as the mutant of DZSY21, the colonization ability of the DZSY21 in maize leaves was clarified through utilizing strain DZSY21 ${ }^{\text {Kan,chl. }}$.

Understand the shape of the DZSY $21^{\text {Kan, chl }}$ by transmission electron microscopy was in favor of estimating whether the strain could colonize plant leaves. The DZSY $21^{\text {Kan,chl }}$ was observed by transmission electron microscopy and presented rhabditiform and globosity (Figure 3B), the shape of the strain DZSY2 $1^{\text {Kan,chl }}$ was the same as that of the wild-type DZSY21 (Figure 3A). Then maize leaves were inoculated with the suspensions $\left(1 \times 10^{8}\right.$ $\mathrm{CFU} / \mathrm{mL})$ of the double-resistance strain DZSY2 ${ }^{\mathrm{Kan}, \mathrm{chl}}(50 \mathrm{~mL}$ per plant), $24 \mathrm{~h}$ after inoculation with the DZSY21 Kan,chl, bacterial cells were found to be localized to the intercellular spaces 


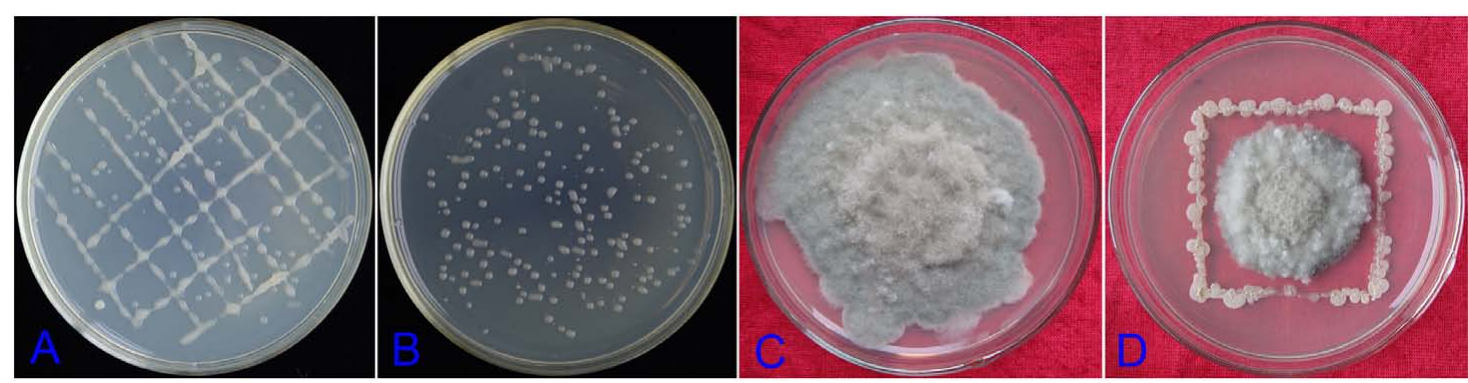

FIGURE 2 | Morphology and antifungal activity of the strain DZSY21 Kan,chl: (A) the morphology of the strain DZSY21; (B) the morphology of the strain

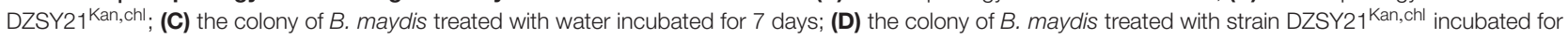
7 days.

of leaf tissues. Furthermore, colonization of the DZSY $21^{\text {Kan,chl }}$ in maize leaves did not have any significant effects on the cell tissues of leaves, chloroplast and starch grains were normal, and the bacterial strain and maize leaves formed a harmonious endophytic relationship (Figures 3D,E). No bacteria were observed in the control plants (Figure 3C). Using the dilution plating method, the population density of the DZSY $21^{\text {Kan,chl }}$ in maize leaves was detected, the population density reached $6.35 \times 10^{3} \mathrm{CFU} / \mathrm{g}$ leaf tissue at 15 days post-inoculation, and remained above $2.17 \times 10^{3} \mathrm{CFU} / \mathrm{g}$ leaf tissue until 30 days post-inoculation. No labeled strains could be isolated from the control plants during the course of the experiments (Figure 3F). Quantification studies revealed the maize leaves were successfully colonized by DZSY21.

\section{Biocontrol on Southern Corn Leaf Blight with DZSY21}

To verify if Bacillus subtilis DZSY21 was able to induce resistance in maize, which might be an indirect factor promoting maize growth, we sprayed the lipopeptides $(1 \mathrm{mg} / \mathrm{mL})$ and DZSY21 suspensions $\left(1 \times 10^{8} \mathrm{CFU} / \mathrm{mL}\right)$ on the leaves of the maize plants (50 $\mathrm{mL}$ per plant), and subsequently challenged leaves with the pathogen $B$. maydis, from the fourth day after the challenge, the symptoms of southern corn leaf blight appeared in all groups, with the prolonging of time of growth, there were obvious differences in the symptoms of maize leaves in different groups. Compared with the negative control (Figure 4A), the plants inoculated with lipopeptides (Figure 4B), DZSY21 suspensions (Figure 4C) and carbendazim wettable powder (Figure 4D) respectively could produce resistance phenotype characterized by the appearance of few small tan necrotic spots on the leaves.

The disease index of the maize leaves was calculated 4 , $6,8,10$, and 15 days after challenge with the pathogen, and was used to detect the resistant response of different groups. The results showed the disease index of the leaves was reduced in all inoculated plants pretreated with the DZSY21, lipopeptides and carbendazim wettable powder as compared with the negative control, and the resistant responses of DZSY21 and its lipopeptides were always better at different period (Figure 4E). At 8 days after challenge with the pathogen $B$. maydis, the disease index of DZSY21 and its lipopeptides were 15.60 and 19.30, respectively (Figure $4 \mathrm{E}$ ), at the same time, the disease index of $50 \%$ carbendazim wettable powder was 32.80 (Figure $4 \mathrm{E}$ ). Pre-treatment with DZSY21 and its lipopeptides also retarded disease development. At the 15 day time point, the disease index of DZSY21 and its lipopeptides were 33.50 and 36.42, respectively, compared to 40.78 for $50 \%$ carbendazim wettable powder (Figure 4E).

The disease reduction of the DZSY21 was evaluated in suppressing southern corn leaf blight development through the disease index assessment measure. The disease reduction was shown in all inoculated plants as compared with the negative control (Table 2). The disease reduction by strains DZSY21 and lipopeptides were $60.41 \%$ and $51.02 \%$ in 8 days after challengedinoculation with the pathogen (Table 2). Pre-treatment with DZSY21, lipopeptides and carbendazim wettable powder also resulted in a slower progression of disease development. By day 15 , the disease reduction of DZSY21, lipopeptides and carbendazim wettable were $42.24,37.24$, and $31.03 \%$, respectively (Table 2). Apparently the best disease reduction was achieved in the treatment with DZSY21, which showed significantly greater disease suppression than the chemical control. The results suggest that the inhibitory effect of lipopeptides is not significantly different than that of DZSY21, indicating that lipopeptides produced by DZSY21 could be the primary mechanism of disease suppression.

\section{Molecular Mass of DZSY21 Lipopeptides}

Bacillus species could produce a structurally diverse group of antimicrobial lipopeptides, including surfactin, iturin, and fengycin families (Wang et al., 2010b; Cai et al., 2013). The lipopeptides of DZSY21 was further characterized by MALDITOF-MS analysis for molecular mass and determination of lipopeptide groups. The DZSY21 lipopeptides contain members of the antifungal surfactin A, surfactin B, and fengycin families. The molecular mass of fengycin in the range $\mathrm{m} / \mathrm{z}$ 1449.8-1491.8 was similar to previous published molecular mass (Pathak et al., 2012) (Figure 5A), mass spectra of fengycin including $\mathrm{m} / \mathrm{z}$ $1449.8,1463.8,1477.8$, and 1491.8 represented lipopeptide groups with different numbers of carbon atoms $(\mathrm{m} / \mathrm{z} 14)$ in their fatty acid chains, and the compound at $\mathrm{m} / \mathrm{z} 1449.8$ represented a $\mathrm{H}$ adduct of fengycin (Figure 5A). The molecular mass of surfactin 

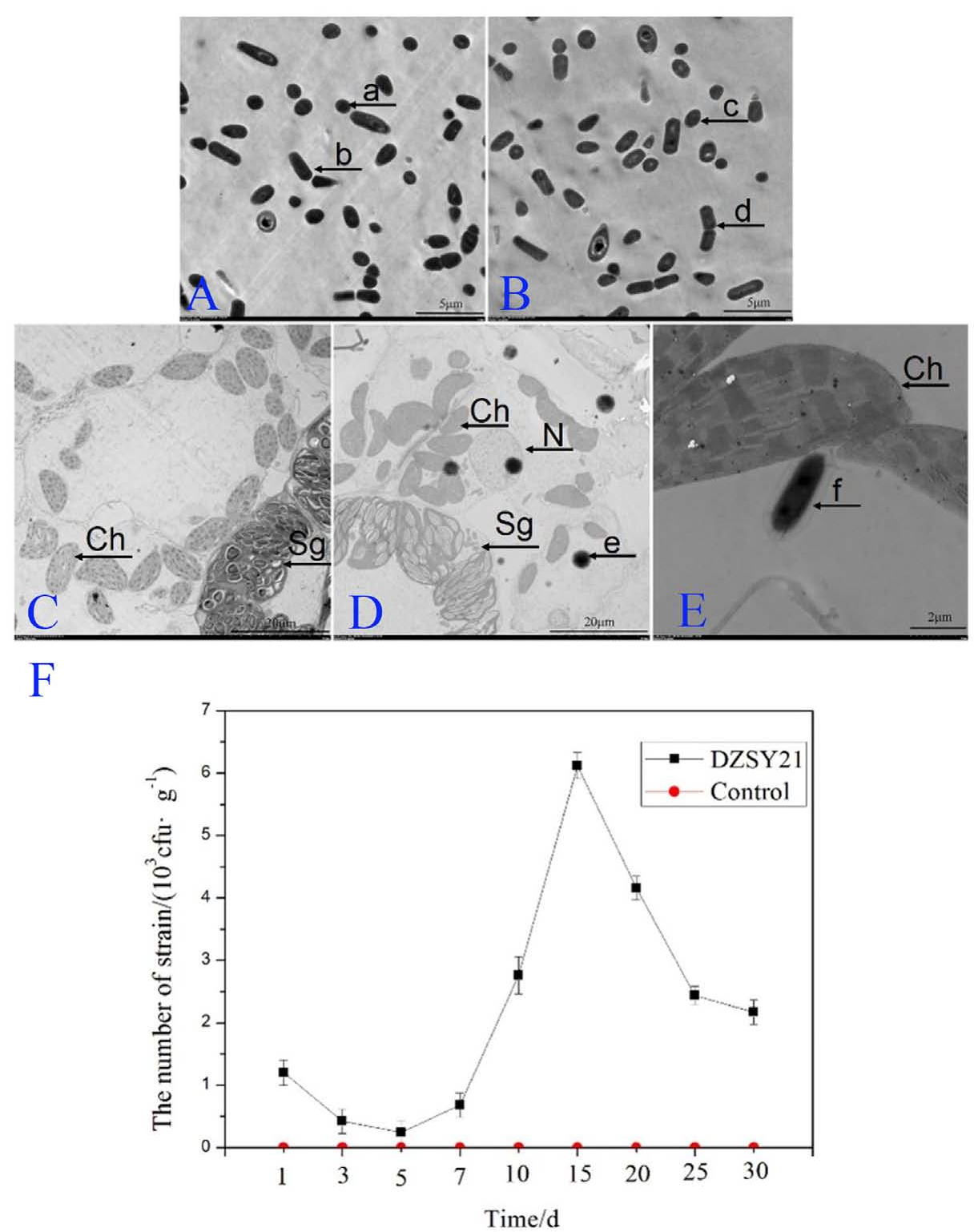

FIGURE 3 | Development of the strain DZSY21 Kan, chl in the maize leaves $\mathbf{2 4} \mathbf{~ h}$ post-inoculation: (A) the different shapes of the wild-type DZSY21 observed by transmission electron microscopy (a, the spherical DZSY21; $\mathbf{b}$, the rod-shaped DZSY21); (B) the different shapes of DZSY21 Kan,chl observed by transmission

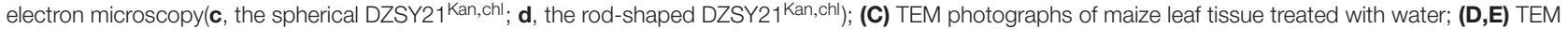
photographs of maize leaf tissue treated with the DZSY21 Kan,chl (Ch, chloroplast; N, Nuclear; Sg, Starch grain; e and f, the DZSY21 Kan, chl), and; (F) population dynamics of the DZSY21 mutant on maize leaf tissue.

$\mathrm{B}$ was in the range of $\mathrm{m} / \mathrm{z}$ 994.6-1032.6. These represented $\mathrm{H}$, $\mathrm{Na}$, and $\mathrm{K}$ adducts of surfactin $\mathrm{B}$, respectively (Figure $5 \mathrm{~B}$ ), and were similar to previous published molecular masses (Mikkola et al., 2004). The other surfactin A was also confirmed by mass spectra of $\mathrm{m} / \mathrm{z} 1022.6-1060.6$, the mass spectra of $\mathrm{m} / \mathrm{z}$ 1022.6-1060.6 represented $\mathrm{H}, \mathrm{Na}$, and $\mathrm{K}$ adducts of surfactin $\mathrm{A}$, respectively (Figure 5C), the mass agrees with previous studies (Luo et al., 2015; Jiang et al., 2016). And the MALDI-TOF-MS characterization did not show any peaks corresponding to iturin lipopeptide.

\section{DZSY21 Mediates the Defense Response in Maize Plants}

To determine the signaling pathways mediated by DZSY21, the expression of target plant genes known to function in the SA or JA/ET pathways were analyzed. Namely PR1 (an SA-responsive marker gene), defensin (PDF1.2) (JA/ET response marker gene), lipoxygenase (LOX) (a JA-responsive marker gene) and an ERF that could be expressed in the plant defense mechanism (Van Loon and Bakker, 2006; Pieterse et al., 2009) were used in this study. Maize leaves were harvested in the 12, 24, 36, 48, and $60 \mathrm{~h}$ 


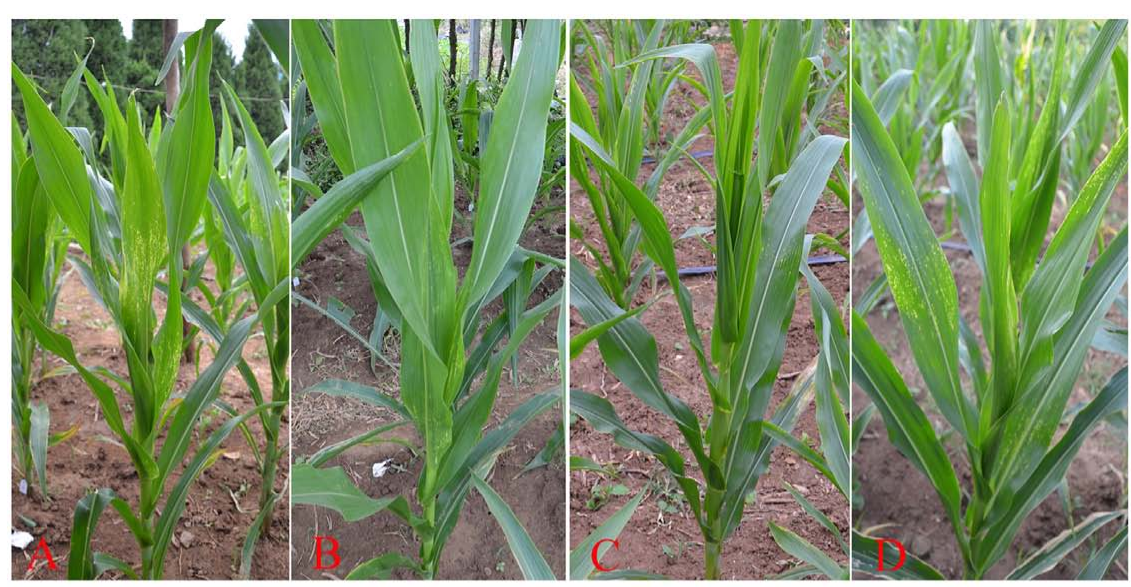

E

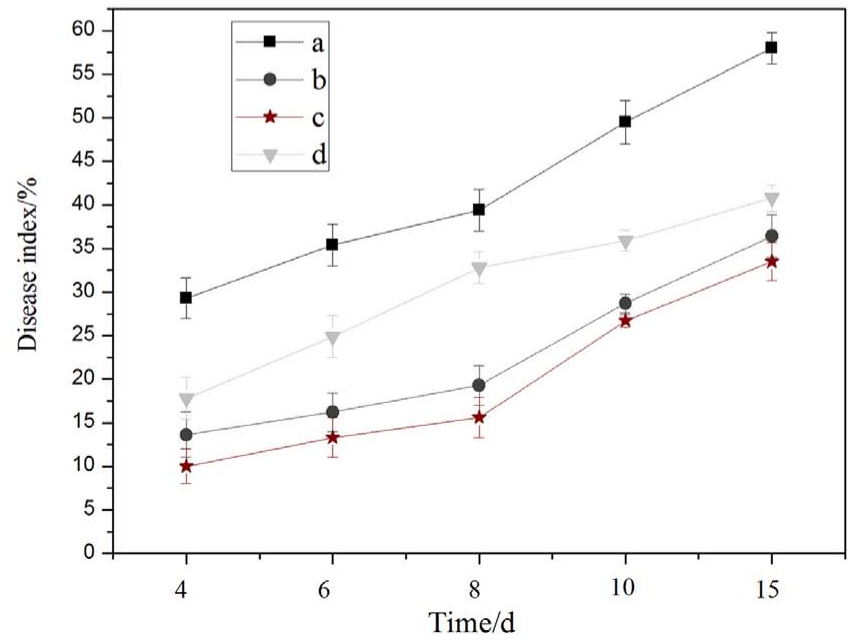

FIGURE 4 | Induction of the systemic resistance in maize plants by Bacillus subtilis DZSY21: (A) plants drenched with a conidial suspension of B. maydis; (B) plants drenched with lipopeptides and then challenged with a conidial suspension of B. maydis; (C) plants drenched with suspensions of DZSY21 and then challenged with a conidial suspension of B. maydis; (D) plants drenched with carbendazim wettable powder and then challenged with a conidial suspension of B. maydis; (E) the graph of disease index of different groups, leaves incubated for $24 \mathrm{~h}$ with (a) water control, (b) lipopeptides, (c) suspension of endophytic strain DZSY21, and (d) 50\% carbendazim wettable powder and then challenged with B. maydis. Disease index was calculated at different days after challenge with B. maydis. Data are expressed as the average of three replicates \pm standard deviation.

separately after inoculation with DZSY21, and the changes in gene expression were analyzed by qRT-PCR.

We observed that the expression of $P R-1$ was strongly induced in DZSY21- treated plants at levels 4.41 - times in $24 \mathrm{~h}$, compared to the control plants treated with water, then expression levels of $P R-1$ were gradually reduced in 36,48 , and $60 \mathrm{~h}$ and the $P R-1$ transcripts were induced to 2.74-, 2.25-, and 2.01-fold, respectively (Figure 6A). The $L O X$ was gradually increased from 12 to $48 \mathrm{~h}$ after inoculation with DZSY21, and the expressions of LOX was strongly induced in DZSY21- treated plants with 4.49times in $48 \mathrm{~h}$, compared to the control plants (Figure 6C). The dynamic of PDF1.2 expression in DZSY21 - treated plants were similar in the expressions of $L O X$, the PDF1.2 transcripts were slightly induced to 1.72-, 1.38-, and 1.41-fold in 36, 48, and $60 \mathrm{~h}$ in DZSY21-treated plants, respectively (Figure 6B). Meanwhile, the expression of ERF in DZSY21-treated plants was lower than in the non-bacterized controls, and the higher expression of ERF was only 0.73 in $48 \mathrm{~h}$ after inoculation with DZSY21 (Figure 6D), indicating the expression was not enhanced in the presence of the DZSY21. These defense-related genes PR1, LOX, and PDF1.2 were concurrently expressed in the leaves of DZSY21-treated plants, suggesting simultaneous activation of the salicylic acid (SA) -and the jasmonic acid (JA) -dependent signaling pathways by DZSY21. There was no evidence of any necrotic lesions in treated plants.

\section{DISCUSSION}

Eucommia ulmoides is a rare and precious plant, and it is not easily infected by plant diseases and insect pests, has a longlife time, and is used in Chinese traditional medicine. 
TABLE 2 | The disease reduction of southern corn leaf blight after leaves treatment with strain DZSY21.

\begin{tabular}{|c|c|c|c|c|c|}
\hline \multirow[t]{2}{*}{ Treatment } & \multicolumn{5}{|c|}{ Disease reduction (\%) } \\
\hline & 4 days & 6 days & 8 days & 10 days & 15 days \\
\hline DZSY21 & $65.87^{a}$ & $62.43^{a}$ & $60.41^{a}$ & $46.06^{a}$ & $42.24^{\mathrm{a}}$ \\
\hline Lipopeptides & $53.58^{b}$ & $54.24^{b}$ & $51.02^{b}$ & $42.02^{b}$ & $37.24^{b}$ \\
\hline $\begin{array}{l}50 \% \text { carbendazim wettable } \\
\text { powder }\end{array}$ & $39.25^{\mathrm{c}}$ & $29.66^{c}$ & $20.81^{c}$ & $27.47^{\mathrm{c}}$ & $31.03^{c}$ \\
\hline Control & - & - & - & - & - \\
\hline
\end{tabular}

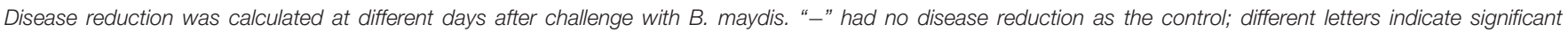
differences between treatments according to Duncan's multiple range test $(\alpha=0.05)$. All experiments were performed at least three times.

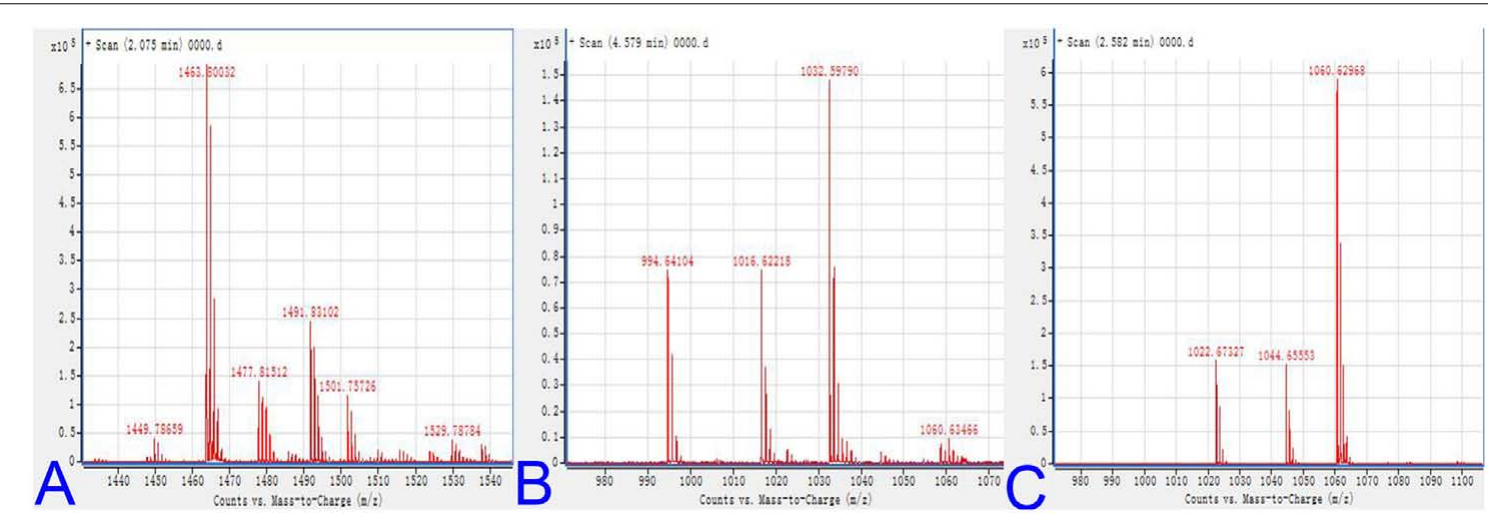

FIGURE 5 | MALDI-TOF mass spectra of lipopeptides: (A) MALDI-TOF mass spectra of lipopeptides for the presence of antibiotic groups fengycin; (B) MALDI-TOF mass spectra of lipopeptides for the presence of antibiotic groups surfactin B; (C) MALDI-TOF mass spectra of lipopeptides for the presence of antibiotic groups surfactin A.

The endophytes isolated from E. ulmoides tissue could have useful functions, such as biocontrol and plant-growth-promoting activities and producing the same bioactive compounds like host plant (Chen et al., 2010; Liu et al., 2016). In this study, the biocontrol mechanisms of DZSY21 against southern corn leaf blight were evaluated. Our results could establish a framework for screening biocontrol strains and inform the design of appropriate protocols for using biocontrol strains.

The efficacy of endophytes as BCAs is dependent on many factors, including: host specificity, population dynamics, pattern of host colonization, and ability to move within host tissues (Backman et al., 1997). Endophytic bacteria need be grown robustly and a considerable population needs to be established in the internal plant tissues. DZSY21 isolated from E. ulmoides leaves were able to enter and colonize the internal leaves of maize, and were able to persist for 30 days. DZSY21 is also capable of colonizing other plants (i.e., lack of host specificity). It has been reported that colonization ability might be linked to certain factors, such as lipopolysaccharides, flagellas, and pili (Compant et al., 2010); further studies will be required to elucidate the mechanisms of colonization in DZSY21.

One of the most important modes of action for endophytic bacteria is antagonism mediated by different compounds with antifungal properties, especially the genus Bacillus. Lipopeptides, such as surfactin, bacillomycin, and fengycin, are major antimicrobial compounds secreted by Bacillus spp., and possess antifungal, antibacterial, immunosuppressive, antitumor, or other physiologically relevant bioactivities (Chen et al., 2008). In this study, the lipopeptides of DZSY21 belonging to Bacillus spp. showed antifungal activity and was highly effective in reducing disease index. The mycelium protoplasm of pathogen exposed to DZSY21 lipopeptides were deformed and contorted. The lipopeptides were characterized by MALDITOF analysis, and were found to contain members of the antifungal surfactin A, surfactin B, and fengycin families. Fengycin and surfactin are strong antifungal compounds secreted by Bacillus spp., which inhibit filamentous fungi by antagonizing sterols, phospholipids, and oleicacid in fungal membranes (Romero et al., 2007; Alvarez et al., 2012). Our results demonstrate that direct antifungal activity was the most dominant method of action of DZSY21 against southern corn leaf blight.

In addition to competition and direct antagonism, endophytic bacteria could control disease through indirect mechanisms. This includes ISR in the host plant, which involves a enhanced capacity to mobilize cellular defense responses before or upon pathogen challenge (Maryline et al., 2007; Verhagen et al., 2010) and induction of stress-related genes expression (Verhagen et al., 2004). ISR has been observed in some PGPB (Pieterse et al., 2001; Pahm et al., 2007; van Loon et al., 2009; Liu et al., 2010). Bacterialmediated ISR involves elicitation of the ISR pathway, generation and translocation of the ISR signal, and ISR signal transduction 


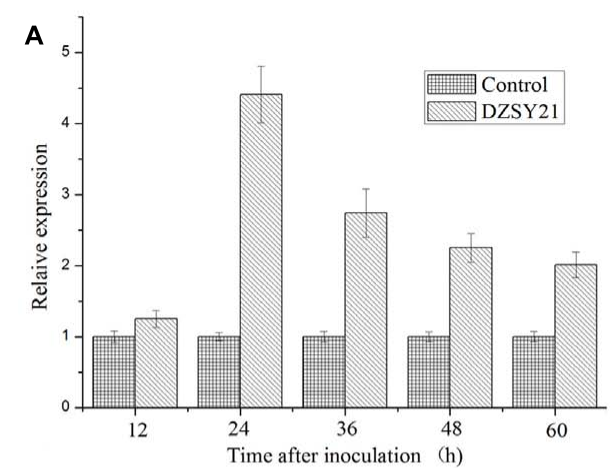

c

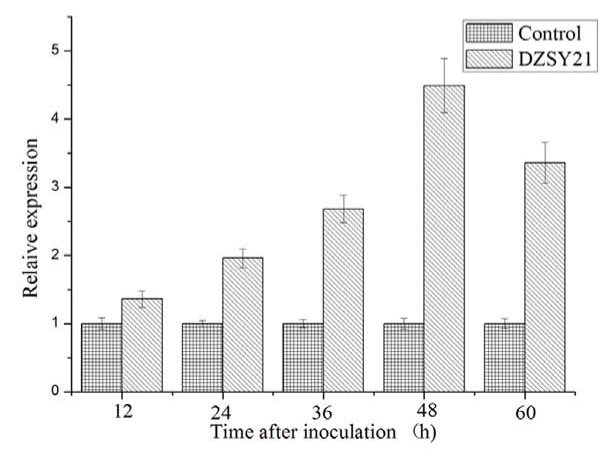

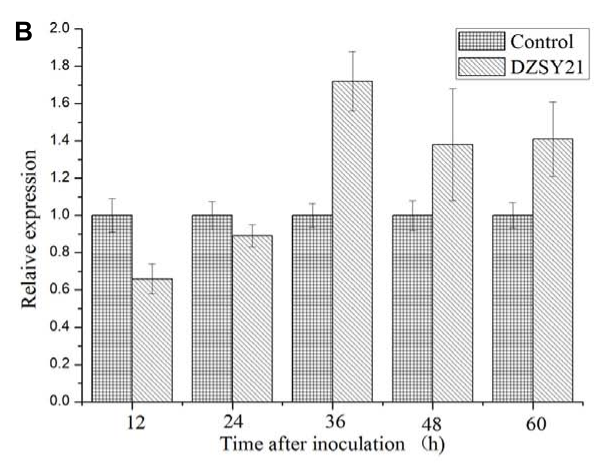

D

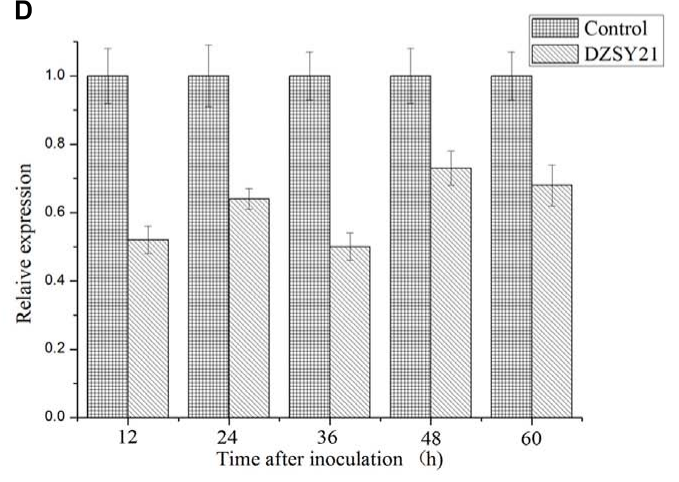

FIGURE 6 | Expression of the key genes involved in the salicylic acid (SA) or jasmonic acid (JA) and ethylene dependent defense signaling pathways in maize in different periods after inoculation. (A) Expression of pathogenesis related protein (PR1); (B) Expression of plant defensing factor (PDF 1.2); (C) Expression of lipoxigenase (LOX); (D) Expression of epidermal repair factor (ERF). The graph shows expression levels of defense marker genes after normalization to the control gene actin. Data are expressed as the average of three replicates \pm standard deviation.

leading to ISR-related gene expression and resistance (Pieterse et al., 2001; Liu et al., 2010).

In maize, there is little information regarding induction of the ISR pathway using endophytic microbes. Only a few studies have been reported showing inducing expression of defense-related genes in maize elicited by beneficial bacteria or exogenous JA (Van Loon and Bakker, 2006). Here, we identified some characteristic genes in maize that are similar to known or deduced functions involved in the SA and JA/ET pathways (Klosterman et al., 2011); these genes are suspected to play a role in generating signals for the activation of certain defense responses and protecting plants from damage associated with defense response. We found that defense-related genes $P R 1$ and LOX were highly expressed in the leaves of DZSY21-treated plants. However, the expression of ERF did not increase. Thus, $L O X$ and $P R 1$ are likely responsible for conferring resistance against $B$. maydis infection in maize. Previously, LOX expression was shown to be stimulated by JA. The application of SA has been shown to trigger the expression of the PR1 gene. ISR is generally independent of the SA signaling pathway and is not associated with major alterations in the expression of defense-related genes, but is rather associated with the priming of defenses (Verhagen et al., 2004; van Loon et al., 2009). It has been wellestablished that there is cross-talk between the SA- and JA/ETdependent signaling pathways (Koornneef and Pieterse, 2008), the SA and JA/ET signaling pathways interact antagonistically stimulating either one leads to the suppression of the other (Koornneef and Pieterse, 2008). However, the results in this study indicate that $L O X$ and $P R 1$ are the defense-related genes responsible for conferring resistance on maize plants by both SA and JA pathways. Some studies have previously reported the induction of genes from both the SA and JA/ET pathways with endophytic microbes (Van Loon and Bakker, 2006), and Niu and associates found the Bacillus cereus AR156, a plant growth-promoting rhizobacterium, mediated ISR to P. syringae DC3000 in Arabidopsis through parallel activation of the SA- and JA/ET-signaling pathways, which leads to an additive effect on the level of induced disease resistance (Niu et al., 2011). Additionally, it has been reported that the Bacillus spp. elicit ISR in several plant species through enhanced peroxidise activity, increased production of chitinase isozymes and glucanase, and accumulation of SA (Kloepper et al., 2004). B. thuringiensis induced resistance to $R$. solanacearum in tomato plants through activation of the SA-dependent signaling pathway and suppression of the JA-dependent signaling pathway (Takahashi et al., 2014). Thus, some researchers have suggested that the specific ISR signal transduction pathway promoted by beneficial microbes is dependent on the strain, the host plant, and/or the pathogen.

In summary, we show that the suppression of southern corn leaf blight in maize by DZSY21 is a result of direct antagonism 
of antifungal lipopeptides produced by the DZSY21, as well as indirect inhibition through ISR. SA- and JA-mediated signal pathways are involved in the induction of ISR. Identifying the mechanisms of different biocontrol agents is important because helps to establish a theoretical basis for the design and appropriate use of biocontrol strains.

\section{AUTHOR CONTRIBUTIONS}

These studies were designed by TD, HJ. BS and XC carried out the major experimental analyses and prepared all figures

\section{REFERENCES}

Akgül, D. S., and Mirik, M. (2008). Biocontrol of phytophthora capsici on pepper plants by bacillus megaterium strains. J. Plant Pathol. 90, 29-34.

Alvarez, F., Castro, M., Príncipe, A., Borioli, G., Fischer, S., Mori, G., et al. (2012). The plant-associated Bacillus amyloliquefaciens strains MEP2 18 and ARP2 3 capable of producing the cyclic lipopeptides iturin or surfactin and fengycin are effective in biocontrol of sclerotinia stem rot disease. J. Appl. Microbiol. 112, 159-174. doi: 10.1111/j.1365-2672.2011.05182.x

Arnold, A. E., Mejía, L. C., Kyllo, D., Rojas, E. I., Maynard, Z., Robbins, N., et al. (2003). Fungal endophytes limit pathogen damage in a tropical tree. Proc. Natl. Acad. Sci. U.S.A. 100, 15649-15654. doi: 10.1073/pnas.2533483100

Augustine, N., Kumar, P., and Thomas, S. (2010). Inhibition of Vibrio cholerae biofilm by AiiA enzyme produced from Bacillus spp. Arch. Microbiol. 12, 1019-1022. doi: 10.1007/s00203-010-0633-1

Backman, P. A., Wilson, M., and Murphy, J. F. (1997). "Bacteria for biological control of plant diseases," in Environmentally Safe Approaches to Crop Disease Control, eds N. A. Rechcigl and J. E. Rechecigl (Boca Raton, FL: CRC Press), 95-105.

Bacon, C. W., and Hinton, D. M. (2002). Endophytic and biological control potential of Bacillus mojavensis and related species. Biol. Control 23, 274-284. doi: $10.1006 /$ bcon.2001.1016

Bajwa, R., Khalid, A., and Cheema, T. S. (2003). Antifungal activity of allelopathic plant extracts III: growth response of some pathogenic fungi to aqueous extract of Parthenium hysterophorus. Plant Pathol. J. 2, 503-507.

Balint-Kurti, P. J., Zwonitzer, J. C., Wisser, R. J., Carson, M. L., Oropeza-Rosas, M. A., Holland, J. B., et al. (2007). Precise mapping of quantitative trait loci for resistance to southern leaf blight, caused by Cochliobolus heterostrophus race $\mathrm{O}$, and flowering time using advanced intercross maize lines. Genetics 176 , 645-657. doi: 10.1534/genetics.106.067892

Bauer, A. W., Kirby, W. M., Sherris, J. C., and Turck, M. (1966). Antibiotic susceptibility testing by a standardized single disk method. Tech. Bull. Reg. Med. Technol. 36, 49-52.

Bennett, A. J., Leifert, C., and Whipps, J. M. (2003). Survival of the biological agents Coniothyrium minitans and Bacillus subtilis MBI600 introduced into pasteurized, sterilized and non-sterile soils. Soil Biol. Biochem. 35, 1565-1573. doi: 10.1016/j.soilbio.2003.08.001

Cai, X. C., Li, H., Xue, Y. R., and Liu, C. H. (2013). Study of endophytic Bacillus amyloliquefaciens CC09 and its antifungal CLPs. J. Appl. Biol. Biotechnol. 1, 1-5.

Chen, C., Bauske, E. M., Rodriguezkabana, R., and Kloepper, J. W. (1995). Biological control of Fusarium wilt on cotton by use of endophytic bacteria. Biol. Control 5, 83-91. doi: 10.1006/bcon.1995.1009

Chen, L., Zhang, Z. Y., Liang, H. X., Liu, H. X., Du, L. P., Xu, H., et al. (2008). Overexpression of TiERF1 enhances resistance to sharp eyespot in transgenic wheat. J. Exp. Bot. 59, 4195-4204. doi: 10.1093/jxb/ern259

Chen, X. M., Sang, X. X., Li, S. H., Zhang, S. J., and Bai, L. H. (2010). Studies on a chlorogenic acid-producing endophytic fungi isolated from Eucommia ulmoides Oliver. J. indus. Microbiol. Biotechnol. 37, 447-454. doi: 10.1007/ s10295-010-0690-0

Choudhary, D. K., and Johri, B. N. (2009). Interactions of Bacillus spp. and plantswith special reference to induced systemic resistance (ISR). Microbiol. Res. 164, 493-513. doi: 10.1016/j.micres.2008.08.007 and tables. SG, QW, and DH complete experiment of plant disease culture inoculation. TD analyzed the data and drafted the manuscript. SX contributed to revisions of the manuscript. $\mathrm{HJ}$ assisted in explaining the results and revised the final version of the manuscript. All authors have read and approved the final manuscript.

\section{ACKNOWLEDGMENT}

This work was supported by the National Natural Science Foundation of China (31371980, 31301324).

Compant, S., Clément, C., and Sessitsch, A. (2010). Plant growth-promoting bacteria in the rhizo- and endosphere of plants: their role, colonization, mechanisms involved and prospects for utilization. Soil Biol. Biochem. 42, 669-678. doi: 10.1016/j.soilbio.2009.11.024

Compant, S., Duffy, B., Nowak, J., Clément, C., and Barka, E. A. (2005). Use of plant growth-promoting bacteria for biocontrol of plant diseases: principles, mechanisms of action, and future prospects. Appl. Environ. Microbiol. 71, 4951-4959. doi: 10.1128/AEM.71.9.4951-4959.2005

Jiang, J., Gao, L., Bie, X. M., Lu, Z. X., Liu, H. X., Zhang, C., et al. (2016). Identification of novel surfactin derivatives from NRPS modification of Bacillus subtilis and its antifungal activity against Fusarium moniliforme. BMC Microbiol. 16:31. doi: 10.1186/s12866-016-0645-3

Kharwar, R. N., Verma, V. C., Strobel, G., and Ezra, D. (2008). The endophytic fungal complex of Catharanthus roseus (L.) G. Don. Curr. Sci. 95, 228-233.

Kloepper, J. W., Ryu, C. M., and Zhang, S. (2004). Induced systemic resistance and promotion of plant growth by Bacillus spp. Phytopathology 94, 1259-1266. doi: 10.1094/PHYTO.2004.94.11.1259

Klosterman, S. J., Anchieta, A., Garcia-Pedrajas, M. D., Maruthachalam, K., Hayes, R. J., and Subbarao, K. V. (2011). SSH reveals a linkage between a senescenceassociated protease and Verticillium wilt symptom development in lettuce (Lactuca sativa). Physiol. Mol. Plant Pathol. 76, 48-58. doi: 10.1016/j.pmpp. 2011.05.003

Koornneef, A., and Pieterse, C. M. (2008). Cross talk in defense signaling. Plant Physiol. 146, 839-844. doi: 10.1104/pp.107.112029

Kunova, A., Bonaldi, M., Saracchi, M., Pizzatti, C., Chen, X. Y., and Cortesi, P. (2016). Selection of Streptomyces against soil borne fungal pathogens by a standardized dual culture assay and evaluation of their effects on seed germination and plant growth. BMC Microbiol. 16:272. doi: 10.1186/s12866016-0886-1

Liu, X. Y., Dou, G. M., and Ma, Y. C. (2016). Potential of endophytes from medicinal plants for biocontrol and plant growth promotion. J. Gen. Plant Pahtol. 82, 165-173. doi: 10.1007/s10327-016-0648-9

Liu, Y. H., Huang, C. J., and Chen, C. Y. (2010). Identification and transcriptional analysis of genes involved in Bacillus cereus -induced systemic resistance in Lilium. Biol. Plant. 54, 697-702. doi: 10.1007/s10535-010-0123-y

Lodewyckx, C., Vangronsveld, J., Porteous, F., Moore, E. R. B., Taghavi, S., Mezgeay, M., et al. (2002). Endophytic Bacteria and their potential applications. Critic. Rev. Plant Sci. 21, 583-606. doi: 10.1080/0735-2602910 44377

Luo, C., Zhou, H., Zou, J., Wang, X., Zhang, R., Xiang, Y., et al. (2015). Bacillomycin $\mathrm{L}$ and surfactin contribute synergistically to the phenotypic features of Bacillus subtilis 916 and the biocontrol of rice sheath blight induced by Rhizoctonia solani. Appl. Microbiol. Biotechnol. 4, 1897-1910. doi: 10.1007/s00253-0146195-4

Maryline, M. R., Patricia, T. A., Daniel, Q., Sylvie, B., and Aziz, A. (2007). Biological control of Botrytis cinerea by selected grapevine-associated bacteria and stimulation of chitinase and $\beta-1,3$ glucanase activities under field conditions. Eur. J. Plant Pathol. 118, 43-57. doi: 10.1007/s10658-007-9111-2

Matsuda, E., Yoshizawa, Y., Yokosawa, Y., Watanabe, N., Kawaii, S., and Murofush, N. (2006). Effects of Eucommia ulmoides oliver leaf extract on 3T3L1 differentiation into adipocytes. J. Nat. Med. 60, 126-129. doi: 10.1007/ s11418-005-0026-y 
Melo, F. M. P. D., Fiore, M. F., Moraes, L. A. B. D., Silva-Stenico, M. E., Scramin, S., Teixeira, M. D. A., et al. (2009). Antifungal compound produced by the cassava endophyte Bacillus pumilus MAIIIM4a. Sci. Agric. 66, 583-592. doi: 10.1590/ S0103-90162009000500002

Mikkola, R., Andersson, M. A., Grigoriev, P., Teplova, V. V., Saris, N. E., Rainey, F. A., et al. (2004). Bacillus amyloliquefaciens strains isolated from moisturedamaged buildings produced surfactin and a substance toxic to mammalian cells. Arch. Microbiol. 4, 314-323.

Nautiyal, C. S., Johri, J. K., and Singh, H. B. (2002). Survival of the rhizospherecompetent biocontrol strains Pseudomonas fluorescences NBR12650 in the soil and phytosphere. Can. J. Microbiol. 7, 588-601. doi: 10.1139/w02-054

Nejad, P., and Johnson, P. A. (2000). Endophytic bacteria induce growth promotion and wilt disease suppression in oilseed rape and tomato. Biol. Control 18, 208-215. doi: 10.1006/bcon.2000.0837

Niu, D. D., Liu, H. X., Jiang, C. H., Wang, Y. P., Wang, Q. Y., Jin, H. L., et al. (2011). The plant growth-promoting rhizobacterium Bacillus cereus AR156 induces systemic resistance in Arabidopsis thaliana by simultaneously activating salicylate and jasmonate/ethylene- dependent signaling pathways. Mol. Plant Microbe Interact. 5, 533-542. doi: 10.1094/MPMI-09-10-0213

Ongena, M., and Jacques, P. (2008). Bacillus lipopeptides: versatile weapons for plant disease biocontrol. Trends Microbiol. 16, 115-125. doi: 10.1016/j.tim.2007. 12.009

Ongena, M., Jacques, P., Touré, Y., Destain, J., Jabrane, A., and Thonart, P. (2005). Involvement of fengycin-type lipopeptides in the multifaceted biocontrol potential of Bacillus subtilis. Appl. Microbiol. Biotechnol. 69, 29-38. doi: 10.1007/ s00253-005-1940-3

Ongena, M., Jourdan, E., Adam, A., Paquot, M., Brans, A., Joris, B., et al. (2007). Surfactin and fengycin lipopeptides of Bacillus subtilis as elicitors of induced systemic resistance in plants. Environ. Microbiol. 9, 1084-1090. doi: 10.1111/j. 1462-2920.2006.01202.x

Pahm, B., Cmj, P., and Lcvan, L. (2007). Induced systemic resistance by fluorescent Pseudomonas spp. Phytopathology 97, 239-243. doi: 10.1094/PHYTO-97-20239

Pathak, K. V., Keharia, H., Gupta, K., Thakur, S. S., and Balaram, P. (2012). Lipopeptides from the banyan endophyte, Bacillus subtilis K1: mass spectrometric characterization of a library of fengycins. J. Am. Soc. Mass Spectrom. 23, 1716-1728. doi: 10.1007/s13361-012-0437-4

Pieterse, C. M. J., Leon-Reyes, A., Ent, S. V. D., and Wees, S. C. M. V. (2009). Networking by smalii-molecule hormones in plant immunity. Nat. Chem. Biol. 5, 308-316. doi: 10.1038/nchembio.164

Pieterse, C. M. J., Pelt, J. A. V., Wees, S. C. M. V., Ton, J., Léonkloosterziel, K. M., Keurentjes, J. J. B., et al. (2001). Rhizobacteria-mediated induced systemic resistance: triggering, signalling and expression. Eur. J. Plant Pathol. 107, 51-61. doi: 10.1023/A:1008747926678

Raaijmakers, J. M., De Bruijn, I., Nybroe, O., and Ongena, M. (2010). Natural functions of lipopeptides from Bacillus and Pseudomonas: more than surfactants and antibiotics. FEMS Microbiol. Rev. 34, 1037-1062. doi: 10.1111/ j.1574-6976.2010.00221.x

Romero, D., de Vicente, A., Rakotoaly, R. H., Dufour, S. E., Veening, J. W., Arrebola, E., et al. (2007). The iturin and fengycin families of lipopeptides are key factors in antagonism of Bacillus subtilis toward Podosphaera fusca. Mol. Plant Microbe Interact. 20, 430-440. doi: 10.1094/MPMI-20-4-0430

Saravanakumar, D., Harish, S., Loganathan, M., Vivekananthan, R., Rajendran, L., Raguchander, T., et al. (2007). Rhizobacterial bioformulation for the effective management of root rot in mungbean. Arch. Phytopathol. Plant Protect. 40, 323-337. doi: 10.1080/03235400600587326

Sessitsch, A., Reiter, B., and Berg, G. (2004). Endophytic bacterial communities of field-grown potato plants and their plant-growth-promoting and antagonistic abilities. Can. J. Microbiol. 50, 239-249. doi: 10.1139/w03-118

Sun, Z. B., Yuan, X. F., Zhang, H., Wu, L. F., Liang, C., and Feng, Y. J. (2013). Isolation, screening and identification of antagonistic downy mildew endophytic bacteria from cucumber. Eur. J. Plant Pathol. 137, 847-857. doi: 10.1007/s10658-013-0293-5

Takahashi, H., Nakaho, K., Ishihara, T., Ando, S., Wada, T., Kanayama, Y., et al. (2014). Transcriptional profile of tomato roots exhibiting Bacillus thuringiensis-induced resistance to Ralstonia solanacearum. Plant Cell Rep. 33, 99-110. doi: 10.1007/s00299-013-1515-1

Tiwari, R., Kalra, A., Darokar, M. P., Chandra, M., Aggarwal, N., Singh, A. K., et al. (2010). Endophytic bacteria from Ocimum sanctum and their yield enhancing capabilities. Curr. Microbiol. 3, 167-171. doi: 10.1007/s00284-0099520-x

Untergasser, A., Nijveen, H., Rao, X., Bisseling, T., Geurts, R., and Leunissen, J. A. (2007). Primer3Plus, an enhanced web interface to primer3. Nucleic Acids Res. 35, 71-74. doi: 10.1093/nar/gkm306

van Loon, L. C., Bakker, P. A., van der Heijdt, W. H., Wendehenne, D., and Pugin, A. (2009). Early responses of tobacco suspension cells to rhizobacterial elicitors of induced systemic resistance. Mol. Plant Microbe Interact. 21, 1609-1621. doi: 10.1094/MPMI-21-12-1609

Van Loon, L. C., and Bakker, P. A. H. M. (2006). "Induced systemic resistance as a mechanism of disease suppression by rhizobacteria," in PGPR: Biocontrol \& Biofertilization, ed. Z. A. Siddiqui (Berlin: Springer), 39-66.

Verhagen, B. W., Glazebrook, J., Zhu, T., Chang, H. S., van Loon, L. C., and Pieterse, C. M. (2004). The transcriptome of rhizobacteria-induced systemic resistance in arabidopsis. Mol. Plant Microbe Interact. 17, 895-908. doi: 10.1094/ MPMI.2004.17.8.895

Verhagen, B. W. M., Trotelaziz, P., Couderchet, M., Höfte, M., and Aziz, A. (2010). Pseudomonas spp.-induced systemic resistance to Botrytis cinerea is associated with induction and priming of defence responses in grapevine. J. Exp. Bot. 61, 249-260. doi: 10.1093/jxb/erp295

Wang, H., Song, J., Zhu, Y., Zhou, Y., and Xiao, M. (2010a). Screening of an antagonistic bacterial strain against plant pathogenic fungi and its antimicrobial mechanism. J. Microbiol. 30, 7-13.

Wang, J., Haddad, N. I., Yang, S. Z., and Mu, B. Z. (2010b). Structural characterization of lipopeptides from Brevibacillus brevis HOB1. Appl. Biochem. Biotechnol. 3, 812-821. doi: 10.1007/s12010-009-8536-9

Wang, M., Ma, J., Fan, L. L., Fu, K. H., Yu, C. J., Gao, J. X., et al. (2015). Biological control of southern corn leaf blight by Trichoderma atroviride SG3403. Bio. Sci. Technol. 25, 1-25. doi: 10.1080/09583157.2015.1036005

Yang, J. H., Kim, I. S., Oh, C. H., and Oh, N. S. (2012). Protease and $\gamma$-glutamyltranspeptidase activities of Bacillus spp. isolated from rice straw. Food Sci. Biotechnol. 1, 291-294. doi: 10.1007/s10068-0120039-8

Zhang, H. C., Liu, R., Zhou, F., Wang, R. M., Liu, X. C., and Zhang, H. T. (2014). Antimicrobial metabolites from the endophytic fungus Aspergillus sp. of Eucommia ulmoides. Chem. Nat. Comp. 3, 526-528. doi: 10.1007/s10600-0141003-Z

Zhou, Z., Zhou, X., Zhong, Z., Wang, C., Zhang, H., Li, D., et al. (2014). Investigation of antibacterial activity of Bacillus spp. isolated from the feces of Giant Panda and characterization of their antimicrobial gene distributions. World J. Microbiol. Biotechnol. 12, 3129-3136. doi: 10.1007/s11274-014-1740-y

Conflict of Interest Statement: The authors declare that the research was conducted in the absence of any commercial or financial relationships that could be construed as a potential conflict of interest.

Copyright (c) 2017 Ding, Su, Chen, Xie, Gu, Wang, Huang and Jiang. This is an open-access article distributed under the terms of the Creative Commons Attribution License (CC BY). The use, distribution or reproduction in other forums is permitted, provided the original author(s) or licensor are credited and that the original publication in this journal is cited, in accordance with accepted academic practice. No use, distribution or reproduction is permitted which does not comply with these terms. 